\title{
Mercury methylation in the hypolimnetic waters of lakes with and without connection to wetlands in northern Wisconsin
}

\author{
C.S. Eckley, C.J. Watras, H. Hintelmann, K. Morrison, A.D. Kent, and O. Regnell
}

\begin{abstract}
Rates of $\mathrm{Hg}$ methylation and demethylation were measured in anoxic hypolimnetic waters of two pristine Wisconsin lakes using stable isotopes of $\mathrm{Hg}$ as tracers. One of the lakes is a clear-water seepage lake situated in sandy terrain with minimal wetland influence. The other is a dark-water lake receiving channelized inputs from a relatively large terrestrial wetland. Methyl mercury $(\mathrm{MeHg})$ accumulated in the anoxic hypolimnia of both lakes during summer stratification, reaching concentrations of $0.8 \mathrm{ng} \cdot \mathrm{L}^{-1}$ in the clear-water lake and $5 \mathrm{ng} \cdot \mathrm{L}^{-1}$ in the dark-water lake. The stable isotopic assays indicated that rate constants of $\mathrm{Hg}^{(\mathrm{II})}$ methylation $\left(K_{\mathrm{m}}\right)$ ranged from 0.01 to $0.04 \cdot \mathrm{day}^{-1}$ in the clearwater lake and from 0.01 to $0.09 \cdot \mathrm{day}^{-1}$ in the dark-water lake, depending on the depth stratum. On average, $K_{\mathrm{m}}$ was threefold greater in the dark-water lake. Hypolimnetic demethylation rate constants $\left(K_{\mathrm{dm}}\right)$ averaged $0.03 \cdot$ day $^{-1}$ in the clear-water lake and $0.05 \cdot \mathrm{day}^{-1}$ in the dark-water lake. These methylation rates were sufficient to account for the observed accumulation of $\mathrm{MeHg}$ in hypolimnetic water during summer in both lakes. Despite substantial export of $\mathrm{MeHg}$ from the wetland to the dark-water lake, our study indicates that in-lake production and decomposition of $\mathrm{MeHg}$ dominated the $\mathrm{MeHg}$ cycle in both lakes.
\end{abstract}

\begin{abstract}
Résumé : L'utilisation des isotopes stables de mercure comme traceurs nous a servi à mesurer les taux de méthylation et de déméthylation de $\mathrm{Hg}$ dans les eaux anoxiques de l'hyplimnion de deux lacs non perturbés du Wisconsin. Un des lacs est un lac à eau claire alimenté par le ruissellement et situé sur un terrain sablonneux avec peu d'influence des terres humides. L'autre est un lac à eau foncée qui reçoit des apports par canalisations provenant d'une grande région de terres humides terrestres. Le méthylmercure s'accumule dans l'hypolimnion anoxique des deux lacs durant l'été, pour atteindre des concentrations de $0,8 \mathrm{ng} \cdot \mathrm{L}^{-1}$ dans le lac à eau claire et $5 \mathrm{ng} \cdot \mathrm{L}^{-1}$ dans le lac à eau foncée. Les dosages d'isotopes stables indiquent que les constantes des taux de méthylation de $\mathrm{Hg}^{(\mathrm{II})}\left(K_{\mathrm{m}}\right)$ varient de 0,01 à $0,04 \cdot$ jour ${ }^{-1}$ dans le lac à eau claire et de 0,01 à $0,09 \cdot$ jour $^{-1}$ dans le lac à eau foncée, en fonction de la profondeur. En moyenne, $K_{\mathrm{m}}$ est trois fois plus élevé dans le lac à eau foncée. Les constantes du taux de déméthylation $\left(K_{\mathrm{dm}}\right)$ dans

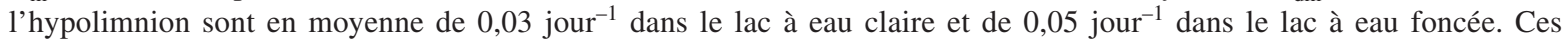
taux de méthylation suffisent à expliquer l'accumulation observée de $\mathrm{MeHg}$ dans les eaux de l'hypolimnion au cours de l'été dans les deux lacs. Malgré une importante exportation de $\mathrm{MeHg}$ des terres humides vers le lac à eau foncée, notre étude indique que la production et la décomposition de $\mathrm{MeHg}$ dans le lac lui-même dominent le cycle de $\mathrm{MeHg}$ dans les deux lacs.
\end{abstract}

[Traduit par la Rédaction]

\section{Introduction}

For decades, elevated levels of $\mathrm{Hg}$ in aquatic systems have been responsible for health advisories on fish consumption in many countries (US Environmental Protection Agency 1997). Pristine lakes receive $\mathrm{Hg}$ inputs through long-range atmospheric transport from industrial sources (Trip and Allan
2000). The majority of $\mathrm{Hg}$ entering lakes from the atmosphere is in the inorganic form; however, essentially all of the $\mathrm{Hg}$ accumulating in fish is methyl mercury ( $\mathrm{MeHg}$ ) (Bloom 1992). Understanding all of the sources of $\mathrm{MeHg}$ to aquatic systems is imperative for the management of $\mathrm{Hg}$ pollution.

There are three main sources of $\mathrm{MeHg}$ to remote lakes: direct precipitation, watershed runoff (especially from wet-

Received 2 December 2003. Accepted 22 November 2004. Published on the NRC Research Press Web site at http://cjfas.nrc.ca on 22 March 2005.

$\mathrm{J} 17868$

C.S. Eckley ${ }^{1,2}$ and H. Hintelmann. Watershed Ecosystems Graduate Program, Trent University, Peterborough, ON K9J 7B8, Canada.

C.J. Watras and K. Morrison. Wisconsin Department of Natural Resources, Madison, WI, 53707, USA, and Trout Lake Station, University of Wisconsin, Boulder Junction, WI 54512, USA.

A.D. Kent. Center for Limnology, University of Wisconsin, Madison, WI 53706-1492, USA.

O. Regnell. Department of Chemical Ecology, University of Lund, Lund, Sweden.

${ }^{1}$ Corresponding author (e-mail: chris.eckley@utoronto.ca).

${ }^{2}$ Present address: Department of Geography, University of Toronto, 3359 Mississauga Road North, Mississauga, ON L5L 1C6, Canada. 
lands), and the in-lake methylation of inorganic $\mathrm{Hg}$ (Rudd 1995). The relative importance of these sources reportedly varies with the rates of $\mathrm{MeHg}$ deposition from the atmosphere, lake type, and catchment hydrology (Rudd 1995). Inlake methylation is known to occur in both littoral sediments (e.g., Gilmour and Riedel 1995) and the anoxic water column (Watras et al. 1995a; Mauro et al. 2002). Historically, there has been an emphasis on methylation in the sediments (Korthals and Winfrey 1987; Ullrich et al. 2001) and inputs from the watershed (St. Louis et al. 1994; Lee et al. 1998) as important sources of $\mathrm{MeHg}$ to lakes. Several mechanisms have been proposed to explain the seasonal accumulation of $\mathrm{MeHg}$ in the anoxic hypolimnia of dimictic lakes including (i) diffusion from profundal sediments to the water column under anoxic conditions (Gagnon et al. 1997; Gill et al. 1999; Ullrich et al. 2001), (ii) methylation in the anoxic water column (Henry et al. 1995; Watras et al. 1995a; Mauro et al. 2002), and (iii) sedimentation of catchment derived particulate $\mathrm{MeHg}$ and methylation in the anoxic water column (Verta and Matilainen 1995).

Although Hultberg et al. (1994) found that inputs of $\mathrm{MeHg}$ from the watershed could account for all of the $\mathrm{MeHg}$ accumulated by fish in a Swedish Lake, and although wetlands have been implicated as important sources of $\mathrm{MeHg}$ to receiving waters (St. Louis et al. 1994; Hurley et al. 1995; Lee et al. 1998), the relative importance of internal and external inputs of $\mathrm{MeHg}$ remains unclear - perhaps varying widely with hydrologic conditions (Sellers et al. 2001). Here, we investigate the internal production of $\mathrm{MeHg}$ in two Wisconsin lakes from very different hydrologic settings. One is a clear-water, precipitation-dominated seepage lake in a relatively small, sandy terrestrial catchment. Previous studies indicate that direct atmospheric deposition is the major source of $\mathrm{Hg}^{(\mathrm{II})}$ and that internal production is the major source of $\mathrm{MeHg}$ for this lake, although the relative importance of littoral versus profundal methylation remains in question (Watras et al. 1995a, 1995b; Krabbenhoft et al. 1998). The other is a dark-water drainage lake that receives most of its water via channelized runoff from a relatively large wetland.

This study uses a new analytical tool (stable isotopes of $\mathrm{Hg}$ ) to build on the findings of previous research on water column methylation in Wisconsin lakes (Watras et al. 1995a; Mauro et al. 2002). The present study uses short incubation times under ambient conditions with low-level spikes of stable $\mathrm{Hg}^{(\mathrm{II})}$ and a more rigorous time series (six time points in $25 \mathrm{~h}$ ) to better quantify rates during the critical early stages of the incubations. We also monitored changes in water chemistry and microbial community structure during the incubations to assess the preservation of in situ lake conditions. A first attempt was made to quantify demethylation rate constants $\left(K_{\mathrm{dm}}\right)$ in these lakes, since $K_{\mathrm{dm}}$ is expected to play a critical role in determining net $\mathrm{MeHg}$ production and accumulation (Hintelmann et al. 2000; Sellers et al. 2001).

\section{Materials and methods}

\section{Site descriptions}

Pallette Lake $\left(45^{\circ} 59^{\prime} \mathrm{N}, 89^{\circ} 42^{\prime} \mathrm{W}\right)$ and Devils Lake $\left(45^{\circ} 31^{\prime} \mathrm{N}, 88^{\circ} 52^{\prime} \mathrm{W}\right)$ are both mesotrophic lakes located in northern Wisconsin, USA. Pallette Lake is a clear seepage lake with a surface area of 70 ha and a maximum depth of $18.3 \mathrm{~m}$. Anoxia develops at approximately $14 \mathrm{~m}$ by midAugust in this lake and the stratification of microbial communities above and below the oxic-anoxic boundary is striking (Watras and Bloom 1994). Devils Lake is a dystrophic drainage lake with a surface area of 12.5 ha and a maximum depth of $7 \mathrm{~m}$. Anoxia develops at around $3.5 \mathrm{~m}$ by midAugust. The inlet stream to Devils Lake emanates from a 24-ha wetland roughly $0.75 \mathrm{~km}$ from the lake. Stream water flowing from the wetland has high concentrations of dissolved organic $\mathrm{C}$ (DOC) $\left(30-85 \mathrm{mg} \mathrm{C} \cdot \mathrm{L}^{-1}\right)$, total $\mathrm{Hg}(\mathrm{HgT})$ $\left(7-16 \mathrm{ng} \cdot \mathrm{L}^{-1}\right)$, and total $\mathrm{MeHg}(\mathrm{MeHgT})\left(0.2-0.8 \mathrm{ng} \cdot \mathrm{L}^{-1}\right)$ and low $\mathrm{pH}$ (3.5-4.5) (C.J. Watras et al., unpublished data). While both lakes are in remote locations in undeveloped watersheds, Devils Lake has a notably higher (roughly four times) $\mathrm{MeHg}$ concentration than Pallette Lake (0.2-0.4 versus $0.03-0.09 \mathrm{ng} \cdot \mathrm{L}^{-1}$, surface).

\section{Field sampling}

In August 2002, Devils Lake and Pallette Lake were sampled using a vertical profiling system (Seabird 19 plus conductivity-temperature-depth (CTD) instrument) that measures several parameters such as dissolved oxygen (DO), beam attenuation, chlorophyll fluorescence, and $\mathrm{pH}$ throughout the water column at a frequency of $4 \mathrm{~Hz}$. The fine-scale biooptical profiles were used to target discrete depths for sampling $\mathrm{Hg}$ species and other analytes. Clean techniques were followed throughout all phases of sample collection, transport, storage, and analysis (US Environmental Protection Agency 1996). Water samples were collected from discrete depths using an all-plastic submersible pump attached to an acrylic outrigger that was fixed to the Seabird CTD. The inlet of the pump was aligned with the CTD sensors and the outlet was attached to $1.3-\mathrm{cm}$ internal diameter C-Flex ${ }^{\mathrm{TM}}$ tubing that ran to the surface. An in-line Nitex screen $(64 \mu \mathrm{m})$ was used to remove zooplankton.

Samples for ambient $\mathrm{Hg}$ analyses were collected in 2-L acid-cleaned glass bottles that were rinsed with lake water three times to condition the bottle walls. Water for methylation and demethylation assays was collected in acid-cleaned $160-\mathrm{mL}$ darkened glass serum bottles that avoided exposure to sunlight. To preserve in situ redox conditions, the incubation bottles were overfilled thrice their volume and capped by displacing air and water through a needle injected into the rubber stopper. Samples were double ziplock bagged for transport in a cooler back to the laboratory. The cooler was monitored with a thermometer and approximate in situ conditions were maintained during transportation (less than $2 \mathrm{~h}$ from collection).

At the Trout Lake Station Laboratory, 460 pg of inorganic ${ }^{199} \mathrm{Hg}$ (92\% pure (Trace Sciences International), stock stored in $0.2 \% \mathrm{HCl}$ and diluted with Milli-Q water to yield the working standard less than 2 weeks before sampling) and $350 \mathrm{pg}$ of $\mathrm{Me}^{201} \mathrm{Hg}$ (98\% pure (Trace Sciences International), synthesized from ${ }^{201} \mathrm{HgO}$ using methylcobalamin, stored in 50/50 $(v / v)$ isopropanol-water and $0.2 \% \mathrm{HCl}$, and diluted with Milli-Q water to yield the working standard less than 2 weeks before sampling) were added to each sample through the ziplock bags via an analytical syringe (Hamilton 
Fig. 1. Methylation time series and regression analysis used to estimate $K_{\mathrm{m}}$ at four hypolimnetic depths in Pallette Lake: (a) $14.0 \mathrm{~m}$, (b) $15.0 \mathrm{~m},(c) 16.0 \mathrm{~m}$, and (d) $17.5 \mathrm{~m}$.

(a)

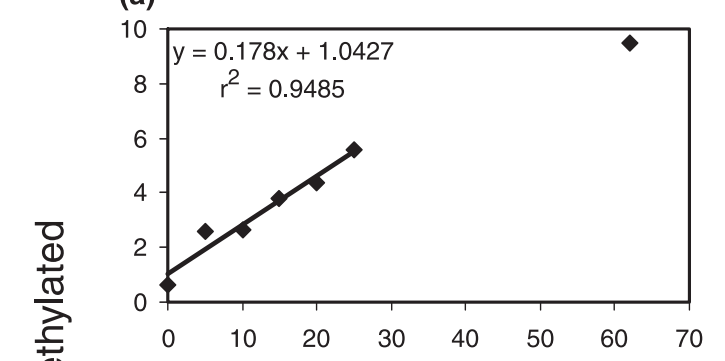

(c)

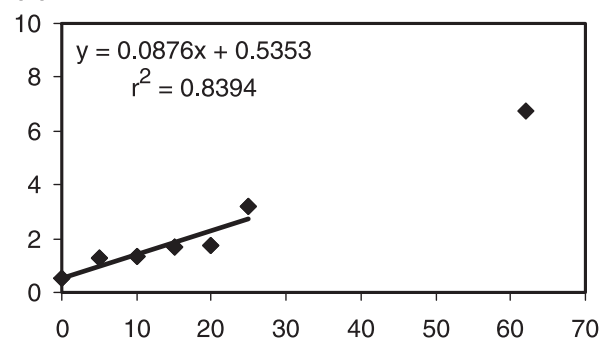

(b)

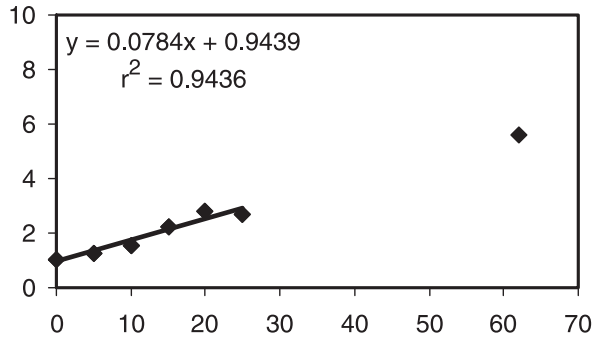

(d)

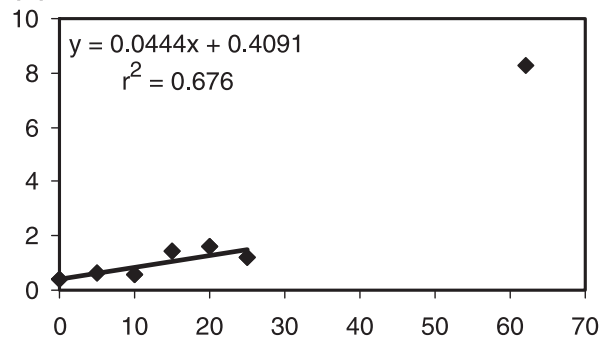

Time (h)

Gastight No. 84880, $25 \mu \mathrm{L}$ ) that punctured the resealable rubber stopper. In Devils Lake, the inorganic ${ }^{199} \mathrm{Hg}$ spike increased the $\mathrm{HgT}$ concentration between $30 \%$ and $50 \%$ and the $\mathrm{Me}^{201} \mathrm{Hg}$ spike increased the MeHgT concentration between $40 \%$ and $125 \%$. In Pallette Lake, the inorganic ${ }^{199} \mathrm{Hg}$ spike increased the $\mathrm{HgT}$ concentration between $200 \%$ and $300 \%$ and the MeHgT was increased between $300 \%$ and $750 \%$. The increase in isotopic $\mathrm{Hg}$ in Pallette Lake may appear large, but the isotopic concentrations of $2.9 \mathrm{ng}$ inorganic ${ }^{199} \mathrm{Hg} \cdot \mathrm{L}^{-1}$ and $2.2 \mathrm{ng} \mathrm{Me}{ }^{201} \mathrm{Hg} \cdot \mathrm{L}^{-1}$ were less than the ambient levels in Devils Lake. Samples were incubated using two refrigerators set to the in situ lake temperatures. Incubations were terminated by addition of $0.5 \mathrm{~mL}$ of concentrated $\mathrm{HCl}$ at 5 -h intervals for the first $25 \mathrm{~h}$ to obtain methylation and demethylation rates. An additional sample at each depth was incubated for $48 \mathrm{~h}$ at Devils Lake and $62 \mathrm{~h}$ at Pallette Lake. The time zero sample was obtained by adding $\mathrm{HCl}$ before the isotopes.

\section{MeHg determination}

Analysis of ambient $\mathrm{Hg}$ species was performed at the Trout Lake Station Laboratory and followed Morrison and Watras (1999). The methylation and demethylation samples were analyzed at Trent University, Ontario, following Hintelmann and Ogrinc (2003). The formation and degradation of $\mathrm{MeHg}$ were determined by monitoring the concentrations of the respective isotopes $\mathrm{Me}^{199} \mathrm{Hg}$ and $\mathrm{Me}^{201} \mathrm{Hg}$. $\mathrm{MeHg}$ was distilled from the incubation samples, which was followed by ethylation, purging with nitrogen gas, trapping on Tenax ${ }^{\circledR}$, thermal desorption, separation by gas chromatography, and detection with an inductively coupled plasma mass spectrometer. $\mathrm{Me}^{202} \mathrm{Hg}(99 \%$ pure (Trace Sciences International)) was added as an internal standard to correct for procedural recoveries. Chromatographic data were collected from the inductively coupled plasma mass spectrometer and peak areas were used to calculate concentrations using a programmed spreadsheet that accounts for procedural blanks and the purities of the isotopes (as described in Hintelmann and Ogrinc 2003).

\section{Methylation and demethylation rate constants}

Following Hintelmann et al. (2000), we used eq. 1 below to calculate the methylation rate constant:

$$
\left[\mathrm{Me}^{199} \mathrm{Hg}_{t}\right]=\left[\mathrm{Me}^{199} \mathrm{Hg}_{t-1}\right]+K_{\mathrm{m}}\left[{ }^{199} \mathrm{Hg}_{t}^{(\mathrm{II})}\right]
$$

where $t$ represents incubation time (h). The methylation rate at each depth was obtained from the slope of the regression line $\left[\mathrm{Me}^{199} \mathrm{Hg}\right]$ versus time fitted to the points for the first $25 \mathrm{~h}$ of the incubation (Figs. 1 and 2). The methylation rate constant $\left(K_{\mathrm{m}}\right)$ was obtained assuming that $\left[{ }^{199} \mathrm{Hg}\right]$ remained constant during this time. Considering the negligible consumption of $\left[{ }^{199} \mathrm{Hg}\right]$ by methylation (the maximum was $<10 \%$ ), this approximation seemed justified, as indicated by the linearity of $\left[\mathrm{Me}^{199} \mathrm{Hg}\right]$ versus time. The methylation potential is expressed as the percent $\mathrm{Me}^{199} \mathrm{Hg}$ formed from the inorganic ${ }^{199} \mathrm{Hg}$ spike $\left(\% \cdot \mathrm{day}^{-1}\right)$ or as the methylation rate constant $K_{\mathrm{m}}\left(\right.$ day $\left.^{-1}\right)$. To determine differences between $K_{\mathrm{m}}$ values at different depths, an analysis of covariance test for parallelism (using the $F$ test) was performed using Statistica $^{\mathrm{TM}}$. The methylation data from Pallette Lake met the parametric assumptions of the analysis of covariance test - the residuals showed homoscedasticity (Levene test, $p>$ 0.05 ) and a normal distribution (Shapiro-Wilk's test, $p>$ $0.05)$, and there was a linear trend between the response variable and covariate (Fig. 1). At Devils Lake, there was a linear trend between the response variable and the covariate (Fig. 2), but the residuals from two of the five sample depths were not homoscedastic (Levene test, $p<0.05$; however, by graphical assessment, no trend was visually discernable), nor 
Fig. 2. Methylation time series and regression analysis used to estimate $K_{\mathrm{m}}$ at five hypolimnetic depths in Devils Lake: (a) $3.0 \mathrm{~m}$, (b) $4.5 \mathrm{~m},(c) 4.9 \mathrm{~m},(d) 5.5 \mathrm{~m}$, and (e) $6.0 \mathrm{~m}$.
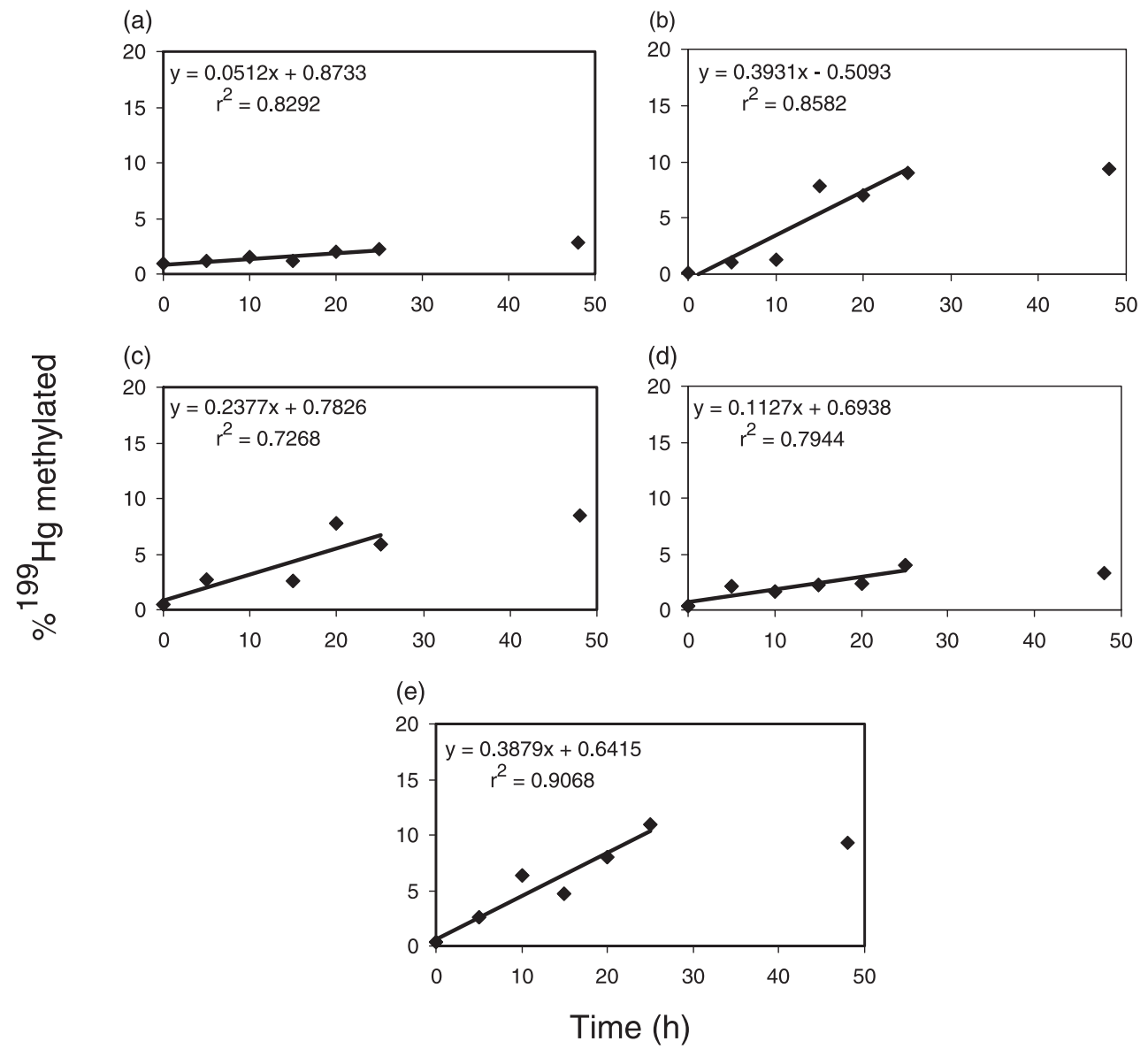

were the residuals normally distributed (Shaprio-Wilk's test, $p<0.0001$ ). Lindman (1974) noted that the $F$ test is remarkably robust to deviations from normality, indicating that it is still appropriate to use this test without transforming the Devils Lake data. For both lakes, the range and average of the Durbin-Watson test statistic for the individual regression time series suggested that significant autocorrelation was not likely to exist because the values were close to 2 (overall: $d=2.0 \pm 0.4$; Devils Lake: $d=2.2 \pm 0.4$; Pallette Lake $d=$ $1.8 \pm 0.3)$. The detection limit for the formation of $\mathrm{Me}^{199} \mathrm{Hg}$ (Hintelmann and Evans 1997) is affected by the ambient $\mathrm{MeHg}$ concentration in the lakes and was $0.011 \mathrm{ng} \cdot \mathrm{L}^{-1}$ at Devils Lake and $0.002 \mathrm{ng} \cdot \mathrm{L}^{-1}$ at Pallette Lake (corresponding to $0.40 \%$ and $0.07 \%$ of the added ${ }^{199} \mathrm{Hg}^{(\mathrm{II})}$ methylated, respectively).

The demethylation rate constant $K_{\mathrm{dm}}$ was obtained from the linear regression of $\ln \left[\mathrm{Me}^{201} \mathrm{Hg}\right]$ versus time (Hintelmann et al. 2000). Based on the variability of the time $=0$ samples, the precision associated with the $\mathrm{Me}^{201} \mathrm{Hg}$ isotope additions was determined to be $11 \%$ (mostly attributed to variability associated with the analytical syringe). None of the demethylation assays had demethylation occurring above the $11 \%$ variability. A $K_{\mathrm{dm}}$ value of $0.12 \cdot \mathrm{day}^{-1}$ (based on a maximum $11 \%$ loss of $\mathrm{Me}^{201} \mathrm{Hg}$ over time) gives an upper limit to demethylation activity. Since we were unable to quantify $K_{\mathrm{dm}}$ at specific depths with reasonable certainty, we pooled the available data and regressed $\ln \left[\mathrm{Me}^{201} \mathrm{Hg}\right]$ versus time for all depths to obtain a global estimate of $K_{\mathrm{dm}}$ in the hypolimnion of each lake. The $90 \%$ confidence intervals bounding the slopes of the two regressions add additional constraints to the probable range of $K_{\mathrm{dm}}$ for a given depth and lake.

\section{Ancillary water chemistry}

Samples for water chemistry analysis were collected in 4-L plastic carboys, except for DOC and sulfide. The DOC samples were filtered through precombusted $0.4-\mu \mathrm{m}$ glass fiber filters (using a precleaned all-glass syringe) into precombusted glass vials with Teflon-lined screw caps. Sulfide samples were collected into $60-\mathrm{mL}$ serum bottles using the overflow technique to exclude oxygen. The serum bottles were sealed with Teflon septa. Dissolved sulfide (detection limit $0.1 \mu \mathrm{mol} \cdot \mathrm{L}^{-1}$ ) was determined using an Orion model 94$16 \mathrm{BN}$ silver/sulfide electrode with an Orion double-junction reference as described by van Gemerden (1987). Analysis for other constituents followed Watras et al. (1995b).

\section{Microbial community analysis}

To assess potential biological changes during the in vitro incubations, we estimated bacterial community composition at the beginning and end of each experiment by automated ribosomal intergenic spacer analysis (ARISA) following a modification of the method of Fisher and Triplett (1999). Similarity of the bacterial community profiles before and after incubation of the samples was analyzed using the 
Table 1. Mercury, MeHg, and ancillary constituents in the water column of Pallette Lake and Devils Lake.

\begin{tabular}{|c|c|c|c|c|c|c|c|c|c|c|c|}
\hline Lake & $\begin{array}{l}\text { Depth } \\
(\mathrm{m})\end{array}$ & $\begin{array}{l}\mathrm{HgT} \\
\left(\mathrm{ng} \cdot \mathrm{L}^{-1}\right)\end{array}$ & $\begin{array}{l}\text { MeHgT } \\
\left(\mathrm{ng} \cdot \mathrm{L}^{-1}\right)\end{array}$ & $\begin{array}{l}\mathrm{DOC} \\
\left(\mathrm{mg} \cdot \mathrm{L}^{-1}\right)\end{array}$ & $\begin{array}{l}\text { SPM } \\
\left(\mathrm{mg} \cdot \mathrm{L}^{-1}\right)\end{array}$ & $\mathrm{pH}$ & 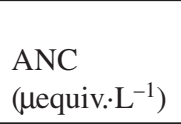 & $\begin{array}{l}\text { Specific } \\
\text { conductivity } \\
\left(\mu \mathrm{S} \cdot \mathrm{cm}^{-1}\right)\end{array}$ & $\begin{array}{l}\text { Total P } \\
\left(\mu g \cdot L^{-1}\right)\end{array}$ & $\begin{array}{l}\mathrm{NO}_{3}-\mathrm{N} \\
\left(\mathrm{mg} \cdot \mathrm{L}^{-1}\right)\end{array}$ & $\begin{array}{l}\mathrm{SO}_{4} \\
\left(\mathrm{mg} \cdot \mathrm{L}^{-1}\right)\end{array}$ \\
\hline Pallette & 3.0 & 0.38 & bd & 5.05 & 2.17 & 6.9 & 108 & 18.8 & 7 & $<0.006$ & 1.82 \\
\hline Pallette & 6.5 & 0.49 & bd & 5.36 & 4.89 & 9.4 & 109 & 28.0 & 13 & $<0.006$ & 1.90 \\
\hline Pallette & 8.5 & 0.42 & bd & 5.31 & 6.43 & 9.3 & 110 & 32.6 & 19 & $<0.006$ & 1.94 \\
\hline Pallette & 9.8 & 0.38 & bd & 4.71 & 4.07 & 6.4 & 111 & 20.0 & 21 & 0.082 & 1.99 \\
\hline Pallette & 16.0 & 1.42 & 0.72 & 4.91 & 6.43 & 6.3 & 193 & 28.3 & 101 & $<0.006$ & 1.58 \\
\hline Pallette & 17.5 & 1.43 & 0.76 & 4.91 & 6.67 & 6.3 & 207 & 32.4 & 109 & 0.021 & 1.52 \\
\hline Devils & 1.5 & 2.25 & 0.34 & 10.75 & 1.17 & 5.6 & 84.6 & 19.1 & 13 & $<0.006$ & 2.80 \\
\hline Devils & 3.0 & 5.02 & 1.72 & 11.04 & 5.34 & 5.5 & 28.3 & 16.9 & 22 & $<0.006$ & 2.98 \\
\hline Devils & 4.5 & 7.40 & 3.36 & 12.15 & 4.94 & 5.7 & 114 & 25.5 & 32 & $<0.006$ & 2.29 \\
\hline Devils & 4.9 & 7.08 & 3.55 & 12.28 & 4.01 & 5.8 & 34.4 & 27.8 & 37 & $<0.006$ & 2.10 \\
\hline
\end{tabular}

Note: The water column was not sampled at a sufficiently fine spatial scale to reveal maxima of $\mathrm{Hg}$ or $\mathrm{MeHg}$ in the hypolimnion, as previously regions of the anoxic-sulfidic water column. The DOC in Pallette Lake is not chromophoric dissolved organic matter (CDOM) of terrestrial origin; Lake DOC is predominantly CDOM originating from a wetland in the terrestrial watershed. SPM, suspended particulate matter; ANC, acid-neutralizing

Sorenson's index of similarity (Magurran 1988). Calculation of Sorenson's indices was carried out using the PRIMER 5 software package (PRIMER-E, Plymouth, UK).

\section{Results and discussion}

\section{Vertical profiles of $\mathbf{H g}$ species and other analytes}

In Pallette Lake, HgT and MeHgT concentrations both increased in the hypolimnion (Table 1; Fig. 3). The percentage of MeHgT to $\mathrm{HgT}$ increased from less than $12.1 \pm 1.4 \%$ (MeHgT was below the detection limit of $0.05 \mathrm{ng} \cdot \mathrm{L}^{-1}$ ) in the epilimnion to $49.4 \pm 4.6 \%$ in the anoxic hypolimnion. Dissolved $\mathrm{MeHg}\left(\mathrm{MeHg}_{\mathrm{d}}\right)$ in the epilimnion (above $8.5 \mathrm{~m}$ ) was below the detection limit of $0.05 \mathrm{ng} \cdot \mathrm{L}^{-1}$ and particleassociated $\mathrm{MeHg}\left(\mathrm{MeHg}_{\mathrm{p}}\right)$ ranged from 0.01 to $0.04 \mathrm{ng} \cdot \mathrm{L}^{-1}$. At $17.5 \mathrm{~m}$, almost all of the $\mathrm{MeHg}$ was dissolved. In the hypolimnion, the amount of $\mathrm{HgT}_{\mathrm{p}}$ that was $\mathrm{MeHg}_{\mathrm{p}}$ was $25 \pm$ $15 \%$, while the percentage of $\mathrm{HgT}_{\mathrm{d}}$ that was $\mathrm{MeHg}_{\mathrm{d}}$ was 75 $\pm 14 \%$, potentially reflecting lower particle reactivity and (or) higher solubility of $\mathrm{MeHg}$ than of $\mathrm{Hg}^{\text {(II) }}$ during sulfidic conditions (Gagnon et al. 1997) or reflecting depletion of dissolved $\mathrm{Hg}^{\text {(II) }}$ by microbial cells and subsequent release of $\mathrm{Hg}$ as $\mathrm{MeHg}$ (Benoit et al. 2001).

In Devils Lake, the $\mathrm{MeHg}$ concentrations were roughly four times higher than in Pallette Lake. As in Pallette Lake, the concentration of $\mathrm{HgT}$ and $\mathrm{MeHgT}$ both increased with depth (Table 1; Fig. 3). In the epilimnion, the percentage of MeHgT to $\mathrm{HgT}$ was $15 \%$, which increased to $52 \pm 6 \%$ in the anoxic hypolimnion. The amount of $\mathrm{Hgd}$ that was $\mathrm{MeHg}$ was $13 \%$ in the epilimnion and increased to $65 \pm 8 \%$ in the anoxic hypolimnion. The percentage of $\mathrm{MeHg}_{\mathrm{p}}$ to $\mathrm{HgT}_{\mathrm{p}}$ was $17 \pm 10 \%$ with no visible trend with depth. Almost all of the $\mathrm{MeHg}$ in the lake was in the dissolved form, with $\mathrm{MeHg}_{\mathrm{p}}$ $<10 \%$ throughout the water column, except at $1.5 \mathrm{~m}$ where $\mathrm{MeHg}_{\mathrm{p}}$ was slightly higher.

The $\mathrm{pH}$ of hypolimnetic water in Devils Lake and Pallette Lake was similar, ranging from 6.1 to 6.3 , which is characteristic of sulfate-reducing environments (Morel 1983).
Specific conductivity and concentrations of major nutrients, anions, and cations were also similar in both lakes, with the exception of potassium, iron, and aluminum, which were higher in Devils Lake. Devils Lake also had slightly higher sulfate concentrations in the epilimnion and slightly lower sulfate concentrations in the hypolimnion compared with Pallette Lake. Consistent with the larger decline in sulfate, there was also a larger buildup of sulfide in the anoxic waters of Devils Lake than in Pallette Lake. The DOC concentration at Devils Lake was roughly twofold higher than at Pallette Lake, but this difference underestimates the relative importance of dissolved allochthonous humic matter in Devils Lake. As evidenced by the high water clarity and the spectral distribution of downwelling light (Watras and Baker 1988), most of the DOC in Pallette Lake comprises autochthonous plankton exudates of low color. In Devils Lake, the deep brown stain and low transparency indicate high concentrations of humic matter of wetland origin.

Possible explanations for the elevated levels of $\mathrm{MeHg}$ in the two hypolimnia include diffusion of $\mathrm{MeHg}$ from the profundal sediments, downward transport of $\mathrm{MeHg}$ by settling particles, and methylation occurring within the anoxic water column. A possible explanation for the higher $\mathrm{MeHg}$ concentrations in Devils Lake than in Pallette Lake is inputs of $\mathrm{MeHg}$ from the wetland affecting Devils Lake. Another possibility is that humic matter, $\mathrm{Hg}^{\text {(II) }}$, and sulfate received from the wetland stimulated the production of $\mathrm{MeHg}$ and increased the stability and retention of $\mathrm{MeHg}$ in the water column of Devils Lake. For both lakes, we used the results from the $\mathrm{Hg}$ methylation and demethylation assays to assess if $\mathrm{MeHg}$ production in the water column could explain the observed buildup of $\mathrm{MeHg}$ during summer stratification (see below).

\section{In vitro incubation conditions}

ARISA profiles generated from the microbial communities present in the incubation bottles at the initial time point and after $25 \mathrm{~h}$ indicated that there was no significant change 


\begin{tabular}{lllllllll}
\hline $\begin{array}{l}\mathrm{H}_{2} \mathrm{~S} \\
\left(\mathrm{mg} \cdot \mathrm{L}^{-1}\right)\end{array}$ & $\begin{array}{l}\mathrm{Cl} \\
\left(\mathrm{mg} \cdot \mathrm{L}^{-1}\right)\end{array}$ & $\begin{array}{l}\mathrm{Ca} \\
\left(\mathrm{mg} \cdot \mathrm{L}^{-1}\right)\end{array}$ & $\begin{array}{l}\mathrm{Mg} \\
\left(\mathrm{mg} \cdot \mathrm{L}^{-1}\right)\end{array}$ & $\begin{array}{l}\text { Total K } \\
\left(\mathrm{mg} \cdot \mathrm{L}^{-1}\right)\end{array}$ & $\begin{array}{l}\mathrm{Na} \\
\left(\mathrm{mg} \cdot \mathrm{L}^{-1}\right)\end{array}$ & $\begin{array}{l}\mathrm{Fe} \\
\left(\mu \mathrm{g} \cdot \mathrm{L}^{-1}\right)\end{array}$ & $\begin{array}{l}\mathrm{Mn} \\
\left(\mu \mathrm{g} \cdot \mathrm{L}^{-1}\right)\end{array}$ & $\begin{array}{l}\text { Total Al } \\
\left(\mu \mathrm{g} \cdot \mathrm{L}^{-1}\right)\end{array}$ \\
\hline na & 0.22 & 2.0 & 0.57 & 0.34 & 0.47 & 11 & 1.6 & $<17$ \\
na & 0.22 & 2.0 & 0.57 & 0.33 & 0.46 & 18 & 3.2 & $<17$ \\
na & 0.34 & 2.1 & 0.61 & 0.38 & 0.40 & 21 & 4.5 & $<17$ \\
na & 0.24 & 2.1 & 0.59 & 0.39 & 0.44 & 35 & 7.6 & $<17$ \\
0.03 & 0.22 & 2.0 & 0.60 & 0.43 & 0.48 & 260 & 48 & $<17$ \\
0.20 & 0.22 & 2.4 & 0.60 & 0.44 & 0.47 & 660 & 63 & 19 \\
0.45 & 0.24 & 2.5 & 0.60 & 0.46 & 0.47 & 800 & 70 & $<17$ \\
0.50 & 0.33 & 2.5 & 0.60 & 0.45 & 0.45 & 870 & 73 & $<17$ \\
0.01 & 0.18 & 1.5 & 0.48 & 0.62 & 0.25 & 360 & 47 & 110 \\
0.01 & 0.22 & 1.9 & 0.49 & 0.80 & 0.27 & 970 & 71 & 150 \\
0.19 & 0.23 & 2.1 & 0.51 & 0.85 & 0.30 & 1800 & 71 & 180 \\
0.31 & 0.23 & 2.1 & 0.51 & 0.86 & 0.66 & 1900 & 71 & 190 \\
0.72 & 0.24 & 2.2 & 0.53 & 0.86 & 0.28 & 2300 & 75 & 210 \\
1.03 & 0.24 & 2.4 & 0.55 & 0.88 & 0.32 & 2800 & 78 & 240 \\
\hline
\end{tabular}

observed in other Wisconsin lakes. The objective here was simply to measure concentrations and rates in various rather, it is colorless dissolved organic matter (DOM), likely derived from plankton exudates. In contrast, Devils capacity; na, not available; bd, below detection limit.

Fig. 3. Depth distribution of waterborne $\mathrm{Hg}$ species (triangles, dissolved; diamonds, particulate) and selected lake parameters. $(a$ and $d$ ) $\mathrm{MeHg}$; $(b$ and $e) \mathrm{Hg}^{(\mathrm{II})}$; ( $c$ and $f$ ) DO $\left(\mathrm{mg} \cdot \mathrm{L}^{-1}\right.$ ), chlorophyll fluorescence (RFU), and beam attenuation (OD) ( $\left.{ }^{-1}\right)$. Note that concentrations of $\mathrm{Hg}$ species that were below detection in the upper water of Pallette Lake are plotted here at the detection limit.

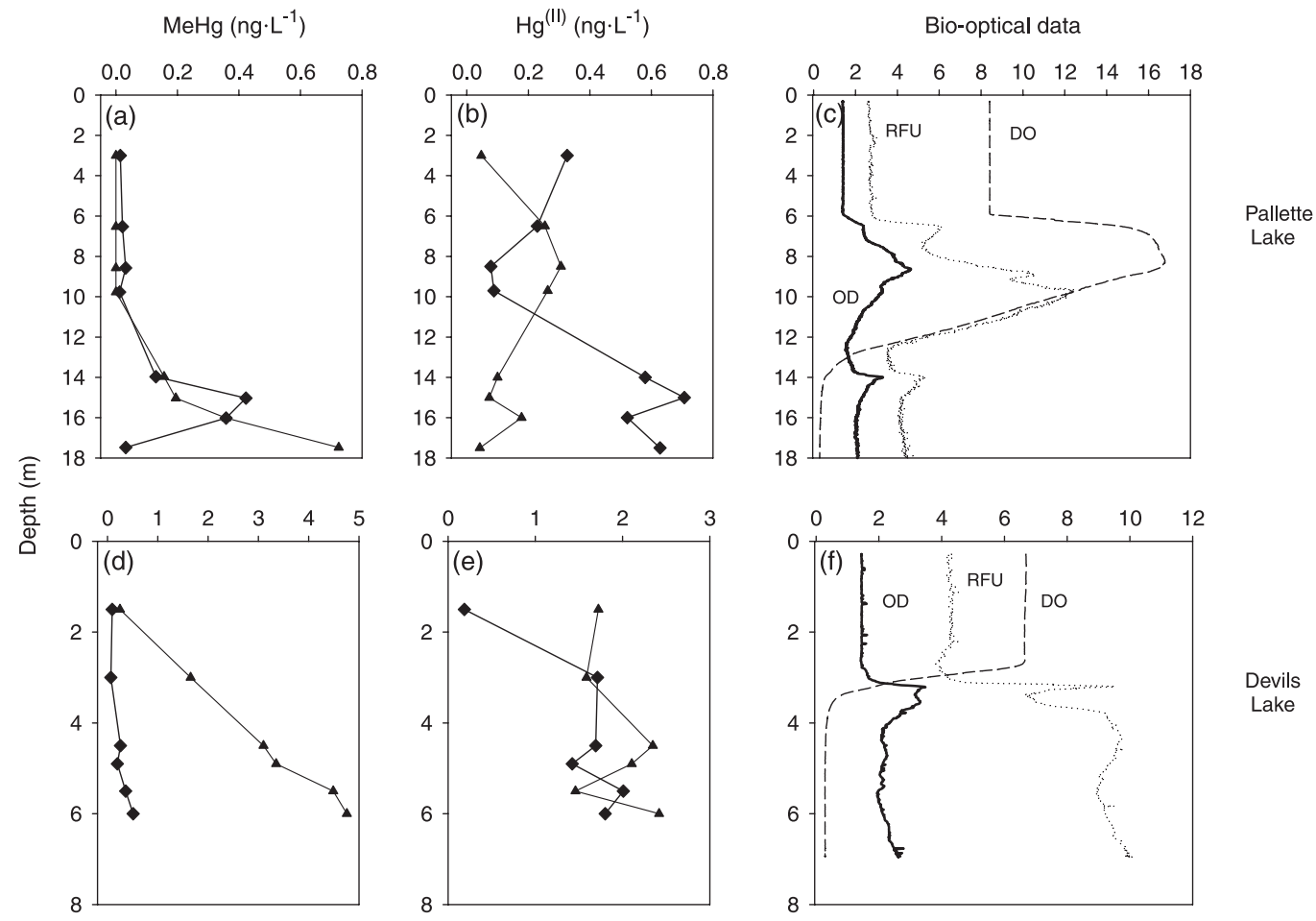

in the composition of the microbial community at any of the depths sampled (Fig. 4). The magnitude of the ARISA peaks does not exactly reflect the abundance of the bacterial population in the original sample due to preferential amplification of some templates during polymerase chain reaction amplification. For this reason, we chose to evaluate only the presence or absence of peaks in comparing ARISA profiles. However, similar results are obtained when peak area is con- sidered using the Bray-Curtis similarity index. Major anions (sulfate, fluoride, nitrate, and phosphate), cations (lithium, sodium, ammonium, potassium, calcium, and magnesium), and DOC were monitored at each incubation time interval and were shown to remain constant through the duration of the experiment (Fig. 5 shows data for sulfate). These data indicate that in situ conditions were maintained during the incubation assays and offer reassurance that the methylation 
Fig. 4. ARISA profiles generated from microbial communities before (solid line) and after (shaded line) incubation for $25 \mathrm{~h}$ in Devils Lake. Sample depth and average Sorenson's index $\left(S_{\text {inc }}\right)$ for comparisons between the initial time point and the replicate profiles from the incubated samples are indicated on each panel along with the Sorenson's index for comparisons between the replicate profiles $\left(S_{\text {rep }}\right)$. The Sorenson's index of similarity indicates the percentage of peaks in common between samples. Variability between ARISA profiles from different time points does not exceed the variation between replicate profiles.

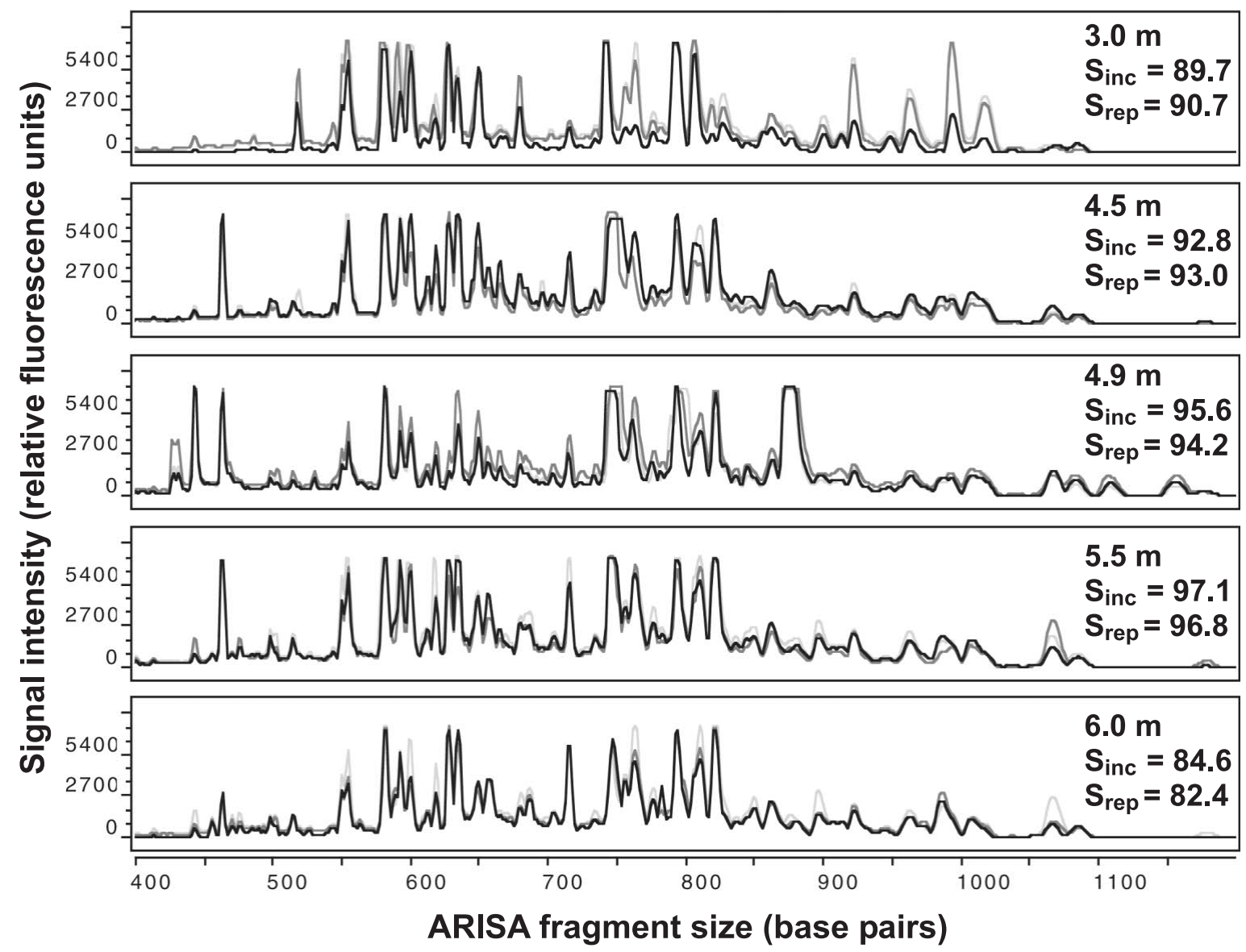

data accurately reflect the in situ methylation activity. However, there is still some uncertainty concerning the bioavailability of the added $\mathrm{Hg}$ and the rates presented are perhaps best considered as the in situ methylation potential (Hintelmann et al. 2000).

\section{Water column methylation and demethylation assays}

The depths sampled at Pallette Lake for $\mathrm{Hg}$ methylation and demethylation assays were 8.5, 13.0, 14.0, 15.0, 16.0, and $17.5 \mathrm{~m}$. These depths were chosen because they coincided with peaks in chlorophyll fluorescence and beam attenuation. No methylation activity was detected at 8.5 and $13.0 \mathrm{~m}$. The water at $8.5 \mathrm{~m}$ was above the oxycline and $13.0 \mathrm{~m}$ was right at the zone of rapid oxygen depletion.

Methylation activity was detected at 14.0, 15.0, 16.0, and $17.5 \mathrm{~m}$ in Pallette Lake (Fig. 1). A peak in methylation activity $\left(4.3 \% \cdot\right.$ day $\left.^{-1}\right)$ was detected at $14.0 \mathrm{~m}\left(F_{[3,16]}=11.65\right.$, $p=0.0003)$. The peak coincided with the appearance of sulfide $\left(0.9 \mu \mathrm{mol} \cdot \mathrm{L}^{-1}\right)$ in the water column, which continued to increase with depth $\left(14.6 \mu \mathrm{mol} \cdot \mathrm{L}^{-1}\right.$ at $\left.17.5 \mathrm{~m}\right)$. Also, at the depth of peak methylation activity $(14.0 \mathrm{~m})$, MeHgT increased by almost one order of magnitude compared with the 10.0-m stratum (the closest overlying depth at which ambient MeHgT was measured). The lower methylation po- tentials at 15.0, 16.0, and $17.5 \mathrm{~m}$ were statistically indistinguishable and averaged $1.7 \pm 0.5 \% \cdot$ day $^{-1}\left(F_{[2,12]}=2.23, p=\right.$ $0.150)$. The MeHgT concentration approximately doubled below $14.0 \mathrm{~m}$ (Table 1), seemingly contradicting the measured methylation rates at these depths. However, as discussed below, a possible explanation for the increasing buildup of $\mathrm{MeHg}$ with increasing depth below $14.0 \mathrm{~m}$ is that methylation started and peaked earlier at the lower depths. The sediment could be an additional source of $\mathrm{MeHg}$, although our modeling work suggests that a sediment source would not be necessary to explain the observed $\mathrm{MeHg}$ levels in the hypolimnion (see following section).

At Devils Lake, the depths chosen for methylation and demethylation assays were: 3.0, 4.5, 4.9, 5.5, and $6.0 \mathrm{~m}$. These depths were chosen because they corresponded to peaks in chlorophyll fluorescence, beam attenuation, and anoxic water. Methylation activity was detected at all of the depths sampled (Fig. 2). The lowest methylation potential was at $3.0 \mathrm{~m}$, which corresponded to the transition zone between oxic and anoxic conditions $\left(\mathrm{DO}=3.53 \mathrm{mg} \cdot \mathrm{L}^{-1}\right)$. Two distinct peaks in methylation activity were detected at 4.5 and $6.0 \mathrm{~m}\left(F_{[4,19]}=7.02, p=0.001\right)$. The two peaks were of very similar size $\left(4.5 \mathrm{~m}: 9.4 \% \cdot \mathrm{day}^{-1} ; 6.0 \mathrm{~m}: 9.3 \% \cdot \mathrm{day}^{-1}\right)$ compared with the potentials detected at the other sample 
Fig. 5. Stability of sulfate concentrations in incubation bottles during in vitro methylation and demethylation assays in Devils Lake. Squares, $3.0 \mathrm{~m}$; diamonds, $4.5 \mathrm{~m}$; triangles, $4.9 \mathrm{~m}$; circles, $5.5 \mathrm{~m}$.

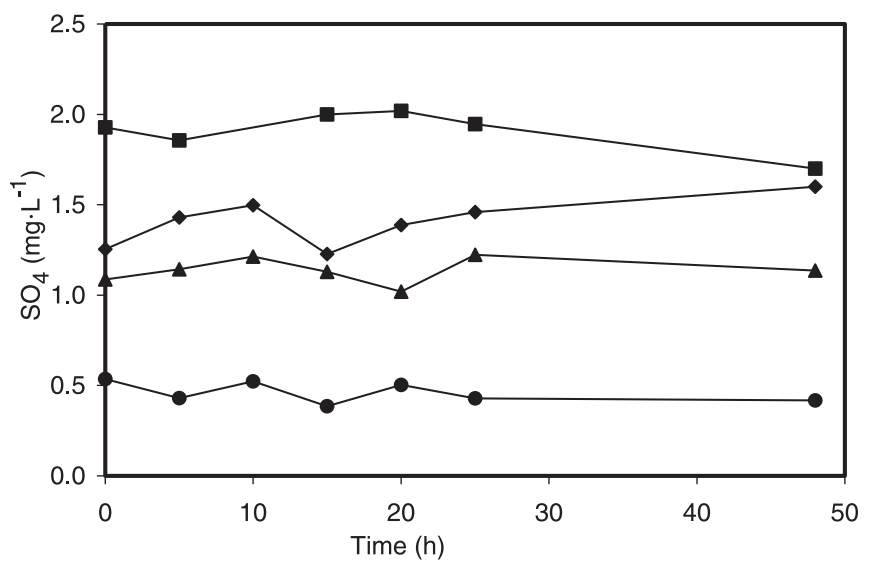

depths $\left(1.2-5.6 \% \cdot\right.$ day $\left.^{-1}\right)$. The peak at $4.5 \mathrm{~m}$ corresponded to an increase in sulfide by over an order of magnitude $(0.4-$ $5.7 \mu \mathrm{mol} \cdot \mathrm{L}^{-1}$ ) and a doubling in the $\mathrm{MeHgT}$ concentration compared with $3.0 \mathrm{~m}$. Following the peak at $4.5 \mathrm{~m}$, the methylation potential decreased at 4.9 and $5.5 \mathrm{~m}$ before the second peak was detected at $6.0 \mathrm{~m}$. Below $4.5 \mathrm{~m}$, the $\mathrm{MeHgT}$ concentration continued to increase between depths sampled but in smaller increments. The concentration of sulfide increased with depth, reaching $30 \mu \mathrm{mol} \cdot \mathrm{L}^{-1}$ at $6.0 \mathrm{~m}$.

The presence of a second peak in methylation potential lower in the water column of equal magnitude to the one below the oxycline has not been observed at other lakes studied (e.g., C.S. Eckley and H. Hintelmann, unpublished data; Watras et al. 1995a; Mauro et al. 2002). The DOC content in Devils Lake was highest at $6.0 \mathrm{~m}\left(13.6 \mathrm{mg} \cdot \mathrm{L}^{-1}\right)$, which, combined with the presence of sulfate at this depth, may have stimulated the activity of some bacteria, while other bacteria were more favored by the higher sulfate concentrations made available farther up in the water column as the oxycline migrated upwards. It is possible that this second peak is unique to shallow lakes containing high nutrient, DOC, and sulfate concentrations under anoxic conditions. Alternatively, as peaks in methylation activity occur at discrete depths $(0.5 \mathrm{~m}$ or less thick), it is possible that other studies may have missed this second peak in methylation closer to the sediment, especially since more attention has been paid to sampling the transition zone between oxic and anoxic conditions (C.S. Eckley and H. Hintelmann, unpublished data; Watras et al. 1995a). We are presently investigating possible relationships between methylation rates and the presence of various bacteria (O. Regnell et al., unpublished data).

In the demethylation assays, the slope of the regressions of $\ln \left[\mathrm{Me}^{201} \mathrm{Hg}\right]$ versus time were negative for both Pallette Lake and Devils Lake, suggesting that demethylation did take place in both hypolimnia, albeit occurring at highly uncertain rates (Fig. 6). Roughly estimated this way, the $90 \%$ confidence interval for $K_{\mathrm{dm}}$ was $0.001-0.37 \cdot$ day $^{-1}$ in Devils Lake and $0.001-0.18 \cdot$ day $^{-1}$ in Pallette Lake. The role of demethylation is further discussed in the source assessment below.
Fig. 6. Demethylation time series for Devils Lake and Pallette Lake pooling available data for all depths in each lake. Regression analysis indicates that slopes are significantly different from zero at a probability level of 0.13 ((a) Devils Lake) and 0.09 ((b) Pallette Lake). The $90 \%$ confidence interval (broken lines) bounding $K_{\mathrm{dm}}$ for Devils Lake extended from 0.02 to $-0.39 \cdot$ day $^{-1}$; for Pallette Lake, it extended from 0.00 to $-0.18 \cdot$ day $^{-1}$.

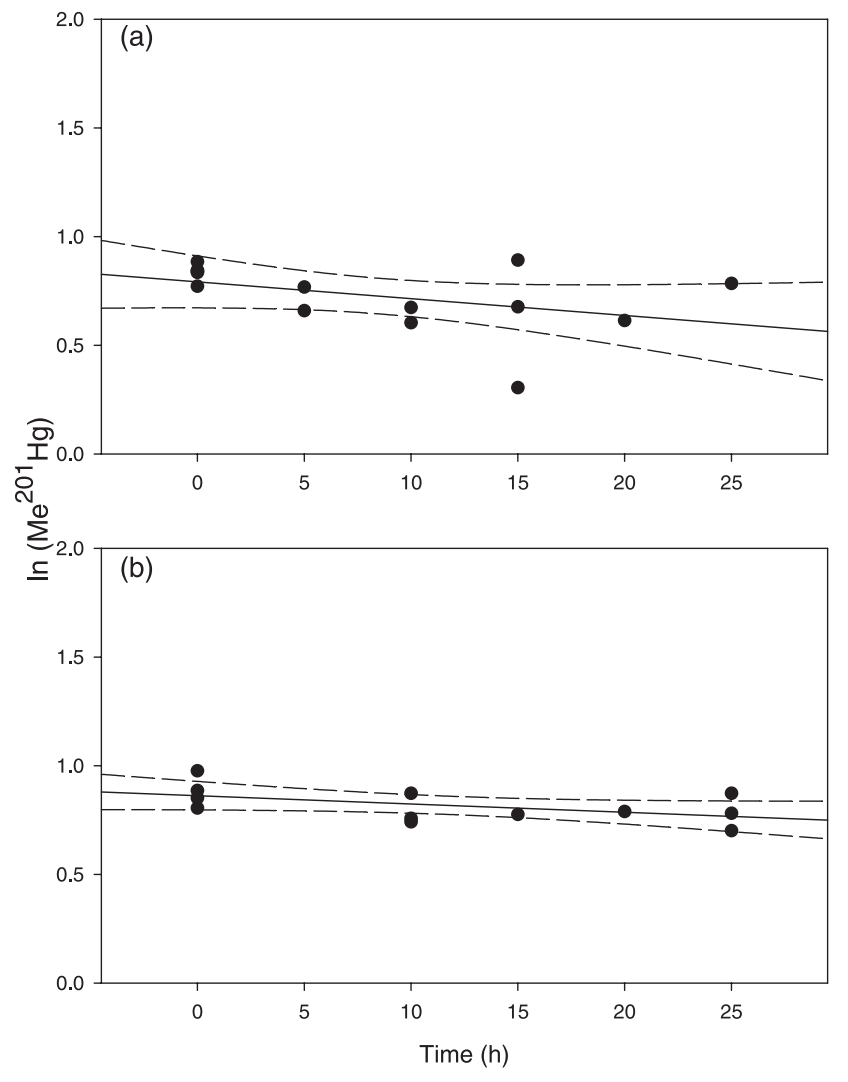

$K_{\mathrm{m}}$ and the buildup of hypolimnetic $\mathrm{MeHg}$

A simple iterative model was used to test whether the experimentally measured rates of water column methylation were sufficient to account for the accumulation of $\mathrm{MeHg}$ in the hypolimnion during summer. The modeling was not designed to take into consideration all of the sources of $\mathrm{MeHg}$ but simply to put the measured $K_{\mathrm{m}}$ values in perspective, thus relying on several simplifications to meet our objective.

Iteration, using daily time steps, started with the measured ambient concentration of $\mathrm{MeHg}$ during spring assuming well-mixed conditions in both lakes (Table 2) and ended with those measured in the fall of 2002 (mid-September) (Table 3) representing a period of 90 days. To match the observed accumulation of $\mathrm{Hg}$ at each depth, the model included an incremental (daily) addition of $\mathrm{Hg}$. This daily addition was estimated for each depth as

$$
\mathrm{Hg}_{\text {input }}=\left(\mathrm{Hg}_{\text {end }}-\mathrm{Hg}_{\text {start }}\right) / 90
$$

The source of the "new" $\mathrm{Hg}$ input could be from settling epilimnetic particles (rainfall or streamflow) and (or) diffusion from the bottom sediments. The speciation of the $\mathrm{Hg}_{\text {input }}$ was assumed to be the same as that in the epilimnetic waterborne pool (i.e., $88 \% \mathrm{Hg}^{\text {(II) }}$ and $12 \% \mathrm{MeHg}$ in Devils Lake based on the mean of five monthly epilimnetic samples 
Table 2. Data indicating that the water columns of both lakes were mixed during the spring.

\begin{tabular}{llcllll}
\hline Lake & Date & $\begin{array}{c}\text { Depth } \\
(\mathrm{m})\end{array}$ & $\begin{array}{l}\mathrm{HgT} \\
\left(\mathrm{ng} \cdot \mathrm{L}^{-1}\right)\end{array}$ & $\begin{array}{l}\mathrm{MeHgT} \\
\left(\mathrm{ng} \cdot \mathrm{L}^{-1}\right)\end{array}$ & $\begin{array}{l}\text { DO } \\
\left(\mathrm{mg} \cdot \mathrm{L}^{-1}\right)\end{array}$ & Temperature $\left({ }^{\circ} \mathrm{C}\right)$ \\
\hline Devils & 30 May 2002 & 1.1 & 3.95 & 0.28 & 8.6 & 19.1 \\
Devils & 30 May 2002 & 2.0 & 4.03 & 0.20 & 9.3 & 14.4 \\
Devils & 30 May 2002 & 5.0 & 4.25 & 0.32 & 5.6 & 8.0 \\
Pallette & 21 March 1990 & 2.0 & 0.67 & 0.067 & 9.83 & 4.8 \\
Pallette & 21 March 1990 & 10.0 & 1.36 & 0.175 & 3.38 & 4.0 \\
Pallette & 21 March 1990 & 18.0 & 2.54 & 1.006 & 0.00 & 4.5 \\
Pallette & 26 April 1990 & 0.3 & 0.43 & 0.040 & 9.95 & 14.4 \\
Pallette & 26 April 1990 & 2.0 & 0.47 & 0.030 & 9.8 & 14.0 \\
Pallette & 26 April 1990 & 6.0 & 1.11 & 0.060 & 9.55 & 8.4 \\
Pallette & 26 April 1990 & 8.0 & 0.61 & 0.030 & 7.81 & 7.0 \\
Pallette & 26 April 1990 & 10.0 & 0.69 & 0.160 & 7.46 & 6.1 \\
Pallette & 26 April 1990 & 12.0 & 0.47 & 0.080 & 6.77 & 5.8 \\
Pallette & 26 April 1990 & 14.0 & 0.67 & 0.080 & 7.21 & 5.5 \\
Pallette & 26 April 1990 & 16.0 & 0.82 & na & 6.12 & 5.4 \\
\hline
\end{tabular}

Note: Devils Lake was measured during turnover, whereas Pallette Lake was measured before and after turnover (as indicated by the large decrease in $\mathrm{HgT}$ and $\mathrm{MeHgT}$ below a depth of $10 \mathrm{~m}$ ). The $\mathrm{HgT}$ and $\mathrm{MeHgT}$ values measured in April and May were used to calculate initial concentrations in the modeling work. na, not available.

collected between May and September 2002 and $90 \% \mathrm{Hg}^{(\mathrm{II})}$ and $10 \% \mathrm{MeHg}$ in Pallette Lake based on 41 epilimnetic samples $(\leq 12.0 \mathrm{~m})$ from eight sample dates between April and September 1998-2002). These values were then entered into eqs. 3 and 4 , which were used to calculate the daily changes in $\mathrm{Hg}$ species for each depth in the absence of any demethylation (i.e., $K_{\mathrm{dm}}=0$ ).

$$
\begin{aligned}
& \mathrm{H}_{t}^{(\mathrm{II})}=\mathrm{Hg}_{t-1}^{(\mathrm{II})}+\mathrm{Hg}_{\text {input }}^{(\mathrm{II})}-K_{\mathrm{m}} \mathrm{Hg}_{t-1}^{(\mathrm{II})} \\
& \mathrm{MeHg}_{t}=\mathrm{MeHg}_{t-1}+\mathrm{MeHg}_{\text {input }}+K_{\mathrm{m}} \mathrm{Hg}_{t-1}^{(\mathrm{II})}
\end{aligned}
$$

where $t$ represents successive days of the 90-day iteration. Iteration over the 90-day period showed that without any demethylation, the measured methylation rates $\left(K_{\mathrm{m}}\right)$ overestimated the accumulation of $\mathrm{MeHg}$ by $207 \%$ in Pallette Lake and by $177 \%$ in Devils Lake. This overestimation of $\mathrm{MeHg}$ indicates the importance of demethylation in lake water and the need to incorporate a demethylation constant $\left(K_{\mathrm{dm}}\right)$, in the model. We calculated the values of $K_{\mathrm{dm}}$ needed to match the measured ambient concentrations at each depth after 90 days using eqs. 5 and 6 :

$$
\begin{aligned}
\mathrm{MeHg}_{t}=K_{\mathrm{m}} \mathrm{Hg}_{t-1}^{(\mathrm{II})}+ & \mathrm{MeHg}_{\text {input }}+\mathrm{MeHg}_{t-1} \mathrm{e}^{-K_{\mathrm{dm}}} \\
\mathrm{Hg}_{t}^{(\mathrm{II})}=\mathrm{Hg}_{t-1}^{(\mathrm{II})}-K_{\mathrm{m}} & \mathrm{Hg}_{t-1}^{(\mathrm{II})} \\
& +\operatorname{MeHg}_{t-1}\left(1-\mathrm{e}^{-K_{\mathrm{dm}}}\right)+\mathrm{Hg}_{\text {input }}^{(\text {II) }}
\end{aligned}
$$

The $K_{\mathrm{dm}}$ values calculated from this procedure averaged 0.034. day ${ }^{-1}$ in the hypolimnion of Pallette Lake and $0.055 \cdot$ day $^{-1}$ in Devils Lake (Table 3). The $K_{\mathrm{dm}}$ values were also measured directly using stable isotopes; however, owing to difficulties in detecting the small decreases in the added isotope over 25-h incubations, they have an associated $90 \%$ confidence interval ranging from 0.02 to $0.39 \cdot$ day $^{-1}$ in Devils Lake and from 0.001 to $0.18 \cdot \mathrm{day}^{-1}$ in Pallette Lake (Fig. 6). The utility of using eqs. 5 and 6 to calculate $K_{\mathrm{dm}}$ is that it provides a more precise measure of demethylation fit- ted to the measured ambient $\mathrm{MeHg}$ concentrations at each depth. At all depths in both lakes, the calculated $K_{\mathrm{dm}}$ values fell within the $90 \%$ confidence interval of the measured demethylation constants. These values for $K_{\mathrm{dm}}$ yielded half-lives for hypolimnetic $\mathrm{MeHg}$ ranging from 1 to 8 weeks. These results indicated that in situ methylation and demethylation could account for the hypolimnetic accumulation of $\mathrm{MeHg}$ at each depth in both lakes during summer. In general, $K_{\mathrm{dm}}$ varied directly with $K_{\mathrm{m}}$, a result that is consistent with the hypothesis that methylation and demethylation in the lowlight environment of anoxic hypolimnia are both biologically driven, perhaps by the same microbes (e.g., MarvinDipasquale and Oremland 1998; Pak and Bartha 1998).

We note that our modeling exercise assumes that $K_{\mathrm{m}}$ and $K_{\mathrm{dm}}$ were constant over the course of the summer, an assumption that we consider unlikely. It seems more likely that $\mathrm{Hg}$ methylation begins in sediments and evolves into the water column as summer progresses. Migration into the water column brings sulfate-reducing bacteria and other microbes closer to the source of important substrates (like sulfate) that have significant atmospheric sources. Proximity to epilimnetic sources of sulfate may confer an advantage to some sulfate-reducing bacteria that compete with methanogens for electron donors (Lovley and Klug 1986). In Devils Lake and Pallette Lake, anoxic conditions develop in June at the sediment-water interface, which is presumably where the zone of highest methylation potential would occur (C.S. Eckley and $\mathrm{H}$. Hintelmann, unpublished data). In August, the zone of highest methylation potential (just below the oxycline) was detected at $14.0 \mathrm{~m}$ in Pallette Lake and $4.5 \mathrm{~m}$ in Devils Lake. Assuming that anoxia developed at a steady rate, the zone of highest methylation potential migrated roughly $1 \mathrm{~m} \cdot \mathrm{month}^{-1}$ up into the water column during the summer.

Our findings do not preclude the importance of methylation and demethylation in littoral sediments. Although the concentration of $\mathrm{MeHg}$ in surface waters is low and relatively constant over the summer, this apparent constancy may simply reflect much higher turnover driven by elevated 


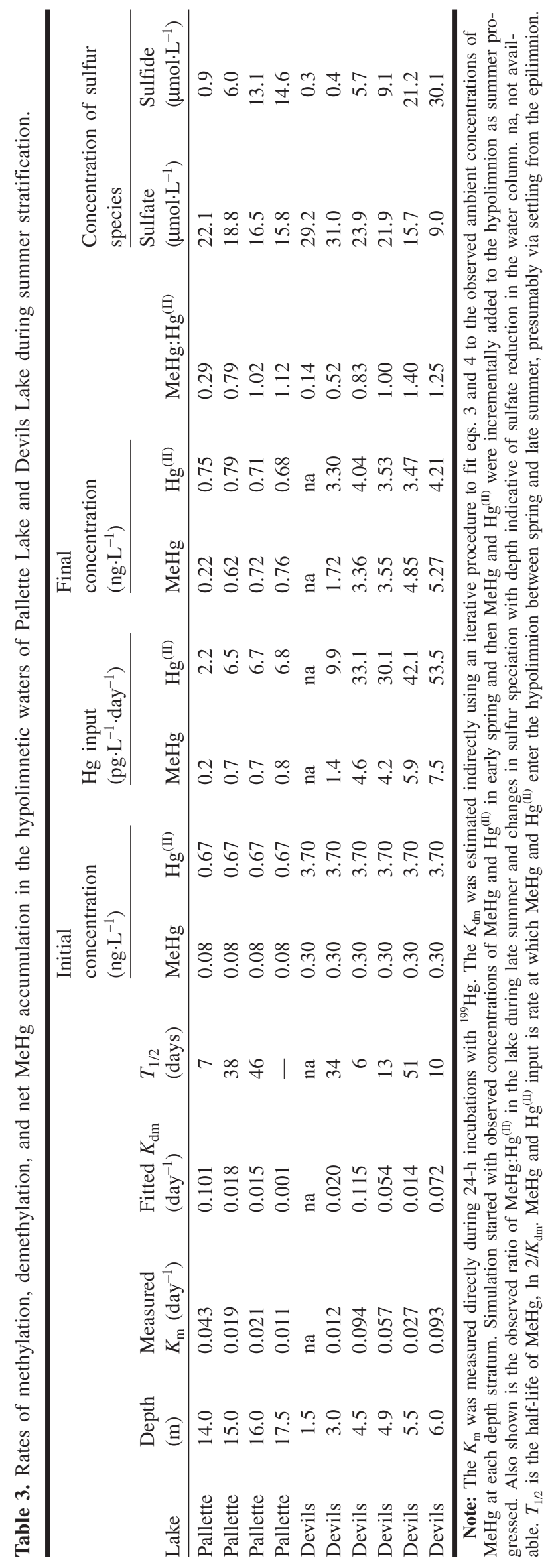


$K_{\mathrm{dm}}$ in surface waters owing to high light intensities and frequent mixing. However, even if $\mathrm{MeHg}$ is produced at high rates in epilimnetic sediments, the presence of an upper oxidized sediment layer may prevent $\mathrm{MeHg}$ from reaching the water (Gagnon et al. 1996; Regnell et al. 2001).

We conclude that $\mathrm{Hg}$ methylation and demethylation occur in the anoxic water columns of Pallette Lake and Devils Lake at rates sufficient to account for the observed accumulation of $\mathrm{MeHg}$ over summer. Both Devils Lake and Pallette Lake had peaks in methylation potential just below the oxycline, which concurs with previous findings for lakes in this region (Watras et al. 1995a; Mauro et al. 2002). In both lakes, the sulfide concentration increased below the oxycline, suggesting that sulfate-reducing bacteria are involved in the process of water column $\mathrm{Hg}$ methylation, and perhaps demethylation as well. Rates of methylation, demethylation, and $\mathrm{MeHg}$ accumulation were all substantially higher in the hypolimnion of the darkwater lake, perhaps because the higher concentrations of DOC and sulfate enhanced $\mathrm{Hg}$ methylating and demethylating microbial activity. In addition, lower light intensity might diminish rates of photodemethylation in the dark-water lake, explaining the higher buildup of $\mathrm{MeHg}$ in the dark-water lake.

Although wetlands are known to produce $\mathrm{MeHg}$ and export it to receiving waters via runoff, the results of this study suggest that the in situ production of $\mathrm{MeHg}$ can be a more important process even when wetlands play a dominant hydrologic role. Preliminary results from our ongoing mass balance studies of Devils Lake support this conclusion (C.J. Watras et al., unpublished data). Those data indicate that the stream emanating from the wetland was the major source of water, DOC, and sulfate to the lake during the year of this study. But even though concentrations of $\mathrm{MeHg}$ in the stream water were higher than those in the epilimnion of the lake (approaching $1 \mathrm{ng} \cdot \mathrm{L}^{-1}$ ), and even though the wetland exported $\mathrm{MeHg}$ at a rate typical for northern wetlands (approximately $0.3 \mu \mathrm{g} \cdot \mathrm{m}^{-2}$ ), the annual input of $\mathrm{MeHg}$ attributable to the wetland accounted for $<20 \%$ of the $\mathrm{MeHg}$ accumulating in the entire water column of the lake. Most of the $\mathrm{MeHg}$ entering the epilimnion via stream inflow was lost via stream outflow during spring and summer. Thus, the dominant source of MeHg to both Devils Lake and Pallette Lake was in situ production. These findings agree with those of Sellers et al. (2001) who estimated the relative importance of all $\mathrm{MeHg}$ sources to be in-lake production $>>>$ inflow from a brown-water lake with riparian wetlands $\gg>$ wet deposition $>$ inflow from a clear-water lake or uplands.

\section{Acknowledgements}

Research was supported by a cooperative agreement with the Potatwatomi Tribal Community of Forest County, Wisconsin. We thank Lawrence Daniels and Larry Lapachin of the Forest County Potawatomi Community (FCPC) for financial and logistical support and Therese Hubacher of the FCPC and Jeff Rubsam of the Wisconsin Department of Natural Resources for technical support in the field and laboratory. This is a contribution from the Trout Lake Laboratory, Center for Limnology, University of Wisconsin-Madison, and the Trent University Water Quality Centre.

\section{References}

Benoit, J.M., Gilmour, C.C., and Mason, R.P. 2001. The influence of sulfide on solid phase mercury bioavailability for methylation by pure cultures of Desulfobulbus propionicus (1pr3). Environ. Sci. Technol. 35: 127-132.

Bloom, N.S. 1992. On the chemical form of mercury in edible fish and marine invertebrate tissue. Can. J. Fish. Aquat. Sci. 49: 1010-1017.

Fisher, M.M., and Triplett, E.W. 1999. Automated approach for ribosomal intergenic spacer analysis of microbial diversity and its application to freshwater bacterial communities. Appl. Environ. Microbiol. 65: 4630-4636.

Gagnon, C., Pelletier, E., Mucci, A., and Fitzgerald, W.F. 1996. Diagenetic behavior of methylmercury in organic-rich coastal sediments. Limnol. Oceanogr. 41: 428-434.

Gagnon, C., Pelletier, E., and Mucci, A. 1997. Behavior of anthropogenic mercury in marine sediments. Mar. Chem. 59: 159-176.

Gill, G.A., Bloom, N.S., Cappellinos, S., Driscol, C.T., Dobbs, C., McShea, L., Mason, R., and Rudd, J.W.M. 1999. Sediment-water fluxes of mercury in Lavaca Bay, Texas. Environ. Sci. Technol. 33: $663-669$.

Gilmour, C.C., and Riedel, G.S. 1995. Measurement of Hg methylation in sediments using high specific-activity ${ }^{203} \mathrm{Hg}$ and ambient incubation. Water Air Soil Pollut. 80: 747-756.

Henry, E.A., Dodgemurphy, L.J., Bigham, G.N., Klein, S.M., and Gilmour, C.C. 1995. Total mercury and methylmercury in an alkaline hypereutrophic urban lake (Onondaga Lake, NY). Water Air Soil Pollut. 80: 509-517.

Hintelmann, H., and Evans, R.D. 1997. Application of stable isotopes in environmental tracer studies - measurement of monomethylmercury $\left(\mathrm{CH}_{3} \mathrm{Hg}^{+}\right)$by isotope dilution ICP-MS and detection of species transformation. Fresenius' J. Anal. Chem. 358: 363-370.

Hintelmann, H., and Ogrinc, N. 2003. Determination of stable mercury isotopes by ICP/MS and their application in environmental studies. In Biogeochemistry of environmentally important trace elements. Edited by Y. Cai and C.O. Braids. American Chemical Society Publishing, Washington, D.C. pp. 321-338.

Hintelmann, H., Keppel-Jones, K., and Evans, D.R. 2000. Constants of mercury methylation and demethylation rates in sediments and comparison of tracer and ambient mercury availability. Environ. Toxicol. Chem. 19: 2204-2211.

Hultberg, H., Iverfeldt, A., and Lee, Y.H. 1994. Methylmercury input, output and accumulation in forested catchments and critical loads for lakes in southwestern Sweden. In Mercury pollution: integration and synthesis. Edited by C.J. Watras and J.W. Huckabee. Lewis Publishers Inc., New York. pp. 313-321.

Hurley, J.P., Benoit, J.M., Babiarz, C.L., Shafer, M.M., Andren, A.W., Sullivan, J.R., Hammond, R., and Webb, D.A. 1995. Influences of watershed characteristics on mercury levels in Wisconsin rivers. Environ. Sci. Technol. 29: 1867-1875.

Korthals, E.T., and Winfrey, M.R. 1987. Seasonal and spatial variations in mercury methylation and demethylation in an oligotrophic lake. Appl. Environ. Microbiol. 53: 2397-2404.

Krabbenhoft, D.P., Gilmour, C.C., Benoit, J.M., Babiarz, C.L., Andren, A.W., and Hurley, J.P. 1998. Methyl mercury dynamics in littoral sediments of a temperate seepage lake. Can. J. Fish. Aquat. Sci. 55: 835-844.

Lee, Y.H., Bishop, K.H., Munthe, J., Iverfeldt, A., Verta, M., Parkman, H., and Hultburg, H. 1998. An examination of current $\mathrm{Hg}$ deposition and export in Fenno-Scandian catchments. Biogeochemistry, 40: 125-135.

Lindman, H.R. 1974. Analysis of variance in complex experimental designs. W.H. Freeman, San Francisco, Calif. 
Lovley, D.R., and Klug, M.J. 1986. Model for the distribution of sulfide reduction and methanogenesis in freshwater sediments. Geochim. Cosmochim. Acta, 50: 11-18.

Magurran, A. E. 1988. Ecological diversity and its measurement. Princeton University Press, Princeton, N.J.

Marvin-Dipasquale, M.C., and Oremland, R.S. 1998. Bacterial methylmercury degradation in Florida Everglades peat sediment. Environ. Sci. Technol. 32: 2556-2563.

Mauro, J.B.N., Guimaraes, J.R.D., Hintelmann, H., Watras, C.J., Haack, E.A., and Coelho-Souza, S.A. 2002. Mercury methylation in macrophytes, periphyton, and water - comparative studies with stable and radio-mercury additions. Anal. Bioanal. Chem. 374: 983-989.

Morel, F.M.M. 1983. Principles of aquatic chemistry. WileyInterscience, New York.

Morrison, K.A., and Watras, C.J. 1999. Mercury and methyl mercury in freshwater seston: direct determination at picogram per litre levels by dual filtration. Can. J. Fish. Aquat. Sci. 56: 760766.

Pak, K.R., and Bartha, R. 1998. Mercury methylation and demethylation in anoxic lake sediments by strictly anaerobic bacteria. Appl. Environ. Microbiol. 64: 1013-1017.

Regnell, O., Hammar, T., Helgee, A., and Troedsson, B. 2001. Effects of anoxia and sulfide on concentrations of total and methyl mercury in sediment and water in two $\mathrm{Hg}$-polluted lakes. Can. J. Fish. Aquat. Sci. 58: 506-517.

Rudd, J.W.M. 1995. Sources of methylmercury to aquatic ecosystems: a review. Water Air Soil Pollut. 80: 697-713.

Sellers, P., Kelly, C.A., and Rudd, J.W.M. 2001. Fluxes of methylmercury to the water column of a drainage lake: the relative importance of internal and external sources. Limnol. Oceanogr. 46: 623-631.

St. Louis, V.L., Rudd, J.W.M., Kelly, C.A., Beaty, K.G., Bloom, N.S., and Flett, R.J. 1994. Importance of wetlands as sources of methyl mercury to boreal forest ecosystems. Can. J. Fish. Aquat. Sci. 51: 1065-1076.

Trip, L., and Allan, R.J. 2000. Sources, trends, implications, and remediation of mercury contamination of lakes in remote areas of Canada. Water Sci. Technol. 42: 171-176.
Ullrich, S.M., Tanton, T.W., and Abdrashitova, S.A. 2001. Mercury in the aquatic environment: a review of factors affecting methylation. Crit. Rev. Environ. Sci. Technol. 31: 241-193.

US Environmental Protection Agency. 1996. Method 1669. Sampling ambient water for trace metals at EPA water quality criteria levels. US Environmental Protection Agency, Office of Water, Engineering and Analysis Division, Washington, D.C.

US Environmental Protection Agency. 1997. 1996 National listing of fish consumption advisories for the United States. US Environmental Protection Agency, Office of Water, Washington, D.C.

van Gemerden, H. 1987. Competition between purple sulfur bacteria and green sulfur bacteria: role of sulfur, sulfide and polysulfides. In Ecology of photosynthetic procaryotes with special reference to meromictic lakes and coastal lagoons. Edited by T. Lindholm. Abo Academy Press, Abo, Finland.

Verta, M., and Matilainen, T. 1995. Methylmercury distribution and partitioning in stratified Finnish forest lakes. Water Air Soil Pollut. 80: 585-588.

Watras, C.J., and Baker, A.L. 1988. The spectral distribution of downwelling light in northern Wisconsin lakes. Arch. Hydrobiol. 112: 481-494.

Watras, C.J., and Bloom, N.S. 1994. The vertical distribution of mercury species in Wisconsin lakes: accumulation in phytoplankton layers. In Mercury pollution: integration and synthesis. Edited by C.J. Watras and J.W. Huckabee. Lewis Publishers Inc., New York. pp. 137-153.

Watras, C.J., Bloom, N.S., Claas, S.A., Morrison, K.A., Gilmour, C.C., and Craig, S.R. 1995a. Methylmercury production in the anoxic hypolimnion of a dimictic seepage lake. Water Air Soil Pollut. 80: 735-745.

Watras, C.J., Morrison, K.A., and Host, J.S. 1995b. Concentration of mercury species in relationship to other site-specific factors in the surface waters of northern Wisconsin lakes. Limnol. Oceanogr. 40: 556-565. 